\title{
Prevalence and Associated Risk Factors of Entamoeba Histolytica Infection Among Schoolchildren From Three Primary Schools In Arsi Town, West Zone, Ethiopia
}

Geribe Bushura Roro

Dilla University

Sunil Tulshiram Hajare ( $\nabla$ sunilhajare@gmail.com )

Dilla University https://orcid.org/0000-0002-6118-9471

Awdah M Al-Hazim

King Abdulaziz University

Mohammed Kuddus

University of Hail

\section{Feleke Eriso}

Dilla University

\section{Research Article}

Keywords: Entameba histolytica, School Children, Microscopy, Antigen detection test, Ethiopia

Posted Date: January 13th, 2022

DOI: https://doi.org/10.21203/rs.3.rs-1202313/v1

License: (c) (i) This work is licensed under a Creative Commons Attribution 4.0 International License.

Read Full License 


\section{Abstract}

Entamoeba histolytica is one of the major pathogenic intestinal parasites and is amongst the leading causes of diarrheal illness in children. Around 500 million people are infected worldwide, while 75,000 die of the disease annually. E. histolytica is associated with moderate to severe diarrhoea and increased mortality among children in African countries and negatively affects child growth and development. Malnutrition is also an important contributor to the prevalence of E. histolytica in Ethiopia. It is mostly associated with poor hygiene, poverty, illiteracy, lack of access to potable water, and a hot, humid tropical climate. Thus, the present investigation was aimed to assess the prevalence rate and associated factors of E. histolytica among schoolchildren in Arsi Town, West Zone, Oromia Regional State, Ethiopia. A crosssectional study was conducted from February 1st to May 1st, 2020. A total of 334 students were selected from three governmental elementary schools in the west zone using a systematic sampling method. A structured questionnaire was adopted to identify environmental, socio-demographic, and behavioral factors. Microscopically positive samples for E. histolytica cysts were further characterised using an E. histolytica II antigen detection kit. The statistical analysis of the data was done using SPSS software. A univariate and multivariate logistic regression analysis was done. $P$ value $<0.05$ was considered statistically significant. The overall prevalence of E. histolytica was $19.8 \%$. Hand washing habits before eating $[A O R=0.32 ; 95 \% \mathrm{Cl}(0.12,0.84)]$, hand washing habits after defecation $[A O R=0.396 ; 95 \% \mathrm{Cl}$ $(0.165,0.946)]$, and ameba awareness $[A O R=0.35 ; 95 \% \mathrm{Cl}(0.142,0.889)]$ were factors associated with parasite prevalence.

\section{Introduction}

Amebiasis is a disease caused by the intestinal parasite Entamoeba histolytica, has an estimated worldwide prevalence of 500 million cases of symptomatic disease, and 40.000-110.000 deaths annually (Haque et al. 2007). It is the 3rd most common parasitic cause of death worldwide (Schmidt and Roberts 2000; Stanley 2003). Disease caused by E. histolytica characterized by self-limited diarrhea but can evolve to long-term complications and malnutrition is one of them. The lifecycle of Entamoeba histolytica involves two distinct morphogenetic stages: the amoeboid and proliferative trophozoite and the infectious cyst form. Infections in humans begin with the ingestion of viable cysts in food or water that has been contaminated by feces. It colonizes the intestinal tract, leading mainly to tissue destruction and secretory bloody diarrhoea (Mendoza Cavazos \& Knoll 2020).

Entamoeba histolytica (Amoebiasis) occurs worldwide; however, the level of prevalence and presentation of symptoms of infection varies geographically. E. histolytica has been covered worldwide, infecting approximately 50 million people annually, causing close to 100,000 deaths per year (WHO 1997). The infection is more prevalent in the tropics and sub-tropics (area of poor sanitation and nutrition) than in colder climates. Morbidity and mortality are present in Africa, Asia, Central and South America (Petri and Singh 2006). 
E. histolytica differs among countries, socio-economical and aseptic conditions, and populations. It is highly pandemic throughout poor and socio-economically deprived communities in the tropics and subtropics. Environmental, socio- economic, demographic, and hygiene-related behavior is known to impact the transmission and distribution of intestinal parasitic infections. Many studies identified that place of residence, age, eating raw vegetables, lack of toilet facility and drinking water quality as important risk factors (file:///C:/Users/welcome/Downloads/entamobia.pdf; Adeyeba and Akinlabi 2002).

As per the UNISEF survey, diarrhea (bloody diarrhea due to amoebiasis infection) is the leading causes of under-five mortality in Ethiopia, accounting for 23 percent, more than 70,000 under age ten children death a year. In Ethiopia, 60 to 80 percent of infectious diseases are due to limited access to potable water, inadequate sanitation and hygiene services. In addition, an estimated 50 percent of the consequences of under nutrition are caused by socioeconomic factors like poor hygiene and lack of access to water supply and sanitation. There are strong relationship between sanitation and stunting, whereas, open defecation can lead to fecal-oral diseases such as diarrhea which is a one of major cause of malnutrition [https://www.unicef.org/ethiopia/water-sanitation-and-hygiene-wash; Beyene et al. 2015). According to survey report of 97 communities of Ethiopia, the overall prevalence of Entameba histolytica infections recorded was 15.0\% in schoolchildren (Erko 1995). In Ethiopia, intestinal parasitic infections (IPIs) including Entamoeba infections are more prevalent in rural areas due to poverty, illiteracy, poor hygiene, lack of access to potable water and hot and humid tropical climate (Mengistu and Berhanu 2004).

Although several studies have been conducted on the distribution and prevalence of amebiasis in Ethiopia, still several localities including study area there is lack of data regarding amoebiasis-related morbidity and mortality. We analyzed death certificate data from the last ten years to assess the prevalence of amoebiasis-related deaths. A total of 248 amoebiasis-related deaths were identified and decided to conduct a study to assess the prevalence, characteristic nature, and risk factors of $E$. histolytica infections among the school children.

\section{Methodology}

\section{Description of study area}

The proposed study was conducted in Arsi Town, West Zone, Oromia Regional State, Ethiopia. The place is located has a longitude and latitude of $7^{\circ} 21^{\prime} \mathrm{N} 38^{\circ} 42^{\prime} \mathrm{E}$ with an elevation of 2043 meters above sea level. In a town, there are six government elementary schools. The three schools, Ashale, Hadansho, and Mako elementary school were included in this study. As per the school record, Ashale $4279(M=2054$ and $\mathrm{F}=2225)$ students, Hadansho has $2717(\mathrm{M}=1360$ and $\mathrm{F}=1357)$ students and Mako elementary school has $3776(\mathrm{M}=1808$ and $F=1968)$ students. The age of the students ranged from 7-20 years.

\section{Research design and study population}


A school based cross-sectional study was conducted to establish the prevalence of E. histolytica infection and associated risk factors among three randomly selected primary school children from Arsi town by simple random and stratified sampling techniques. The students were first stratified according to their educational level (Grade 1 to Grade 8 ) in selected school and allocation of students was done in proportional to the number of students in each school and grade level. Finally, the students were selected using systematic random sampling by using class roster as the sampling frame.

\section{Sample size determination}

The sample size was determined by the formula as used by Daniel (1999)

$N=(Z a 22) P(1-P) / d 2$

Where,

$\mathrm{N}=$ sample size

$\mathrm{P}=$ prevalence rate of E. histolytica reported by Feleke Eriso (2014), $(\mathrm{P}=32 \%$ or 0.32$)$

$d=$ margin of sampling error $(d=0.05)$.

Based on the above formula:

$N=(1.96)^{2} * 0.32(1-0.32) /(0.05)^{2}=1.96^{2} * 0.32 * 0.68 /(0.05)^{2}=334$.

Based on the calculation the total sample size for the study was 334 . The actual number of students who participated in the study were selected using a simple random sampling technique to incorporate 334 students.

\section{Stool samples and Data collection}

After giving proper instruction on how to collect the stool sample, each school children were supplied the clean, dry collection cups with unique identification numbers, with applicator sticks and instructed to bring at least $10 \mathrm{~g}$ of proper fresh stool sample in small bottles. Date of sampling, number of the participant, grade, section, school name, age, and sex were recorded. Each sample was divided into 2 parts. First part immediately was transported to the laboratory and examined within $30 \mathrm{~min}$ of collection of the sample to avoid disintegration of trophozoites. Fecal samples (formol-ether concentrations) were examined for the presence of ova, cysts, and larvae. Second part of unfixed stool sample was stored at $-20^{\circ} \mathrm{C}$ for performing Entamoeba histolytica antigen detection test (Parija et al. 2014).

Data on demographic and determinant was collected by trained laboratory assistant by using a structured questionnaire. The questionnaire was prepared originally in English and then translated into the local language of Oromo and Amharic.

\section{Laboratory analysis procedures}


The stool samples were processed by direct wet smear and formalin ethyl acetate sedimentation technique followed by iodine staining and examined via microscopy for the presence of E. histolytica (Fig. 1). Microscopically positive samples for E. histolytica cysts were further characterized using antigen detection kit. Diagnosis was based on the identification of Entamoeba histolytica worm eggs or larvae, protozoan trophozoites, and cysts.

\section{Entamoeba histolytica antigen detection}

The antigen detection E. histolytica II test (TechLab, Inc., Blacksburg, VA) was performed on unfixed fresh stool samples containing E. histolytica cysts according to the manufacturer's instructions. This was done to detect the non- pathogenic form of Entamoeba (E. dispar) (Haque et al. 2000). The kits were provided by USAID under Health Workforce Improvement Program in Ethiopia.

\section{Data analysis}

Data was entered and analyzed using SPSS software version 20.0. Descriptive statistics was done to calculate frequencies and percentages. The associations of potential risk factors and presence of $E$. histolytica infection were performed by binary logistic regression analysis model (Hosmer and Lemeshow 2000). Multivariate logistic regression analysis was used to measure the strength of association of sociodemographic factors and E. histolytica infection. Ninety five percent confidence interval (Cl) was calculated for the odds ratio value. The results of the association were considered as significant when the $p$ value was below 0.05 .

\section{Results}

\section{Socio-demographic characteristics of the study subjects}

Three hundred thirty four, school children were recruited and included in the analysis, with a $100 \%$ response rate. There were $165(49.4 \%)$ males and 169 (50.6\%) females. The major age ranges of the participants were from five to seventeen years. Most of the study participants, 170 (50.9\%) were 1 to 4 grade level. Regarding the educational status of the father's, above diploma was 94 (28.1\%). 110 (32.9\%) mother's educational level was limited up to write and read only. 39.5 percent of fathers were merchant whereas 42.9 percent of mothers were housewife by occupation (Table 1 ). 
Table 1

Socio-demographic characteristics of study participants

\begin{tabular}{|c|c|c|c|}
\hline Variables & Category & Frequency & Percent (\%) \\
\hline \multirow[t]{2}{*}{ Sex } & Male & 165 & 49.4 \\
\hline & Female & 169 & 50.6 \\
\hline \multirow[t]{3}{*}{ Age category } & $5-9$ & 105 & 31.4 \\
\hline & $10-14$ & 197 & 59.0 \\
\hline & $>15$ & 32 & 9.6 \\
\hline \multirow[t]{2}{*}{ Grade category } & $1-4$ & 170 & 50.9 \\
\hline & $5-8$ & 164 & 49.1 \\
\hline \multirow[t]{5}{*}{ Father's educational status } & Unable to write and read & 38 & 11.4 \\
\hline & Able to write and read only & 73 & 21.9 \\
\hline & Elementary school & 55 & 16.5 \\
\hline & Secondary school & 74 & 22.2 \\
\hline & Above diploma & 94 & 28.1 \\
\hline \multirow[t]{5}{*}{ Mother's educational status } & Unable to write and read & 27 & 8.1 \\
\hline & Able to write and read only & 110 & 32.9 \\
\hline & Elementary school & 61 & 18.3 \\
\hline & Secondary school & 86 & 25.7 \\
\hline & Above diploma & 50 & 15.0 \\
\hline \multirow[t]{4}{*}{ Father's occupation } & Merchant & 132 & 39.5 \\
\hline & Government worker & 122 & 36.5 \\
\hline & Daily laborer & 30 & 9.0 \\
\hline & Farmer & 50 & 15.0 \\
\hline \multirow[t]{5}{*}{ Mother's occupation } & House wife & 143 & 42.8 \\
\hline & Merchant & 127 & 38.0 \\
\hline & Government worker & 29 & 8.7 \\
\hline & Daily laborer & 24 & 7.2 \\
\hline & Farmer & 11 & 3.3 \\
\hline
\end{tabular}




\section{Frequency distribution of behavioral and environmental related factors}

A large number, 312 (93.4\%) of the students had tap water of drinking water source. Regarding drinking water storage, $62.3 . \%$ of the households had jerican and $6 \%$ of the household keeps the water uncovered. $76.4 \%$ did not treat the drinking water by chlorine or boiling. $100 \%$ had the toilet facility at home constructed in and around the compound. Of households who had toilets, 59.3\% were lacking water access in toilet. $66.5 \%$ of household had no sewage disposal facility, $31.7 \%$ of the student had no habit of washing hands before eating whereas, $21.3 \%$ had the habit of washing hands after detraction with soap. $91.0 \%$ of the study participants were aware about the importance of nail trimming. Only $21.0 \%$ had awareness about amoebiasis (Table 2) 
Table 2

Behavioral and environment related factors.

\begin{tabular}{|c|c|c|c|}
\hline Variable & Category & Frequency & Percent \\
\hline \multirow[t]{3}{*}{ Source of drinking water } & Tap & 312 & 93.4 \\
\hline & Ground & 22 & 6.6 \\
\hline & Water & & \\
\hline \multirow[t]{4}{*}{ Water storage } & Tank & 69 & 20.7 \\
\hline & Jerican & 214 & 62.3 \\
\hline & Baldy & 34 & 10.2 \\
\hline & Clay spot & 23 & 6.9 \\
\hline \multirow[t]{2}{*}{ Status of water container } & Covered & 314 & 94.0 \\
\hline & Uncovered & 20 & 6.0 \\
\hline \multirow[t]{2}{*}{ Treatment of water at home } & Yes & 85 & 25.4 \\
\hline & No & 249 & 74.6 \\
\hline \multirow[t]{2}{*}{ Presence of latrine at home } & Yes & 334 & 100.0 \\
\hline & No & - & - \\
\hline \multirow[t]{2}{*}{ Presence of water at latrine } & Yes & 136 & 40.7 \\
\hline & No & 198 & 59.3 \\
\hline \multirow[t]{2}{*}{ Sewage disposal } & Garbage pit & 112 & 33.5 \\
\hline & Outside the compound & 222 & 66.5 \\
\hline \multirow[t]{2}{*}{ Hand wash habit before eating } & Yes & 267 & 79.9 \\
\hline & No & 67 & 20.1 \\
\hline \multirow[t]{3}{*}{ Hand wash habit after defecation } & No & 106 & 31.7 \\
\hline & Water only & 157 & 47.0 \\
\hline & Water and soap & 71 & 21.3 \\
\hline \multirow[t]{2}{*}{ Habit of eating unwashed fruits } & Yes & 208 & 62.3 \\
\hline & No & 126 & 37.7 \\
\hline \multirow[t]{2}{*}{ Dirty materials in the fingers } & Yes & 105 & 31.4 \\
\hline & No & 229 & 68.6 \\
\hline Habit of nail trim & Yes & 304 & 91.0 \\
\hline
\end{tabular}




\begin{tabular}{|llll|}
\hline Variable & Category & Frequency & Percent \\
\hline \multirow{2}{*}{ Awareness about ameba } & No & 30 & 9.0 \\
& Yes & 70 & 21.0 \\
\cline { 2 - 4 } & No & 264 & 79.0 \\
\hline
\end{tabular}

Prevalence of E. histolytica

Microscopy and E. histolytica II antigen detection kit were used to test single stool specimens from 334 asymptomatic school children aged 5 to 17 years. Microscopy was positive in 94 (28.14\%) stool samples (Data not shown) for E. histolytica and antigen detection test was positive in 66 (19.76\%) stool specimens (Table 3). Among the study subjects, 165 were males and 169 were females. Higher prevalence of $E$. histolytica was found in males compared with female students. Regarding, the $E$. histolytica infection in specific age group, children with age group 5-9 was more infected than other age groups of study subjects but this is not significant difference due to unequal sample size. Out of 334 students, 84, 117, and 133 were belongs to Ashale, Hadansho and Mako elementary school respectively. The highest prevalence was observed in Ashale primary school children (Table 3).

Table 3

Overall prevalence of E. histolytica

\begin{tabular}{|c|c|c|c|c|}
\hline Variables & Categories & No of sampled & E. histolytica positive & E. histolytica negative \\
\hline \multirow[t]{2}{*}{ Sex } & Male & 165 & $34(20.6 \%)^{*}$ & $131(79.4 \%)$ \\
\hline & Female & 169 & $32(18.9 \%)$ & $137(81.1 \%)$ \\
\hline \multirow[t]{3}{*}{ Age groups (years) } & $5-9$ & 106 & $23(21.7 \%)$ & $83(78.3 \%)$ \\
\hline & $10-14$ & 198 & $38(19.2 \%)$ & $160(80.8 \%)$ \\
\hline & $>15$ & 30 & $5(16.7 \%)$ & $25(83.3 \%)$ \\
\hline \multirow[t]{2}{*}{ Grade level } & $1-4$ & 170 & $34(20.0 \%)$ & $136(80.0 \%)$ \\
\hline & $5-8$ & 164 & $32(19.5 \%)$ & $132(80.5 \%)$ \\
\hline \multirow[t]{3}{*}{ Schools } & Ashale & 84 & $21(25 \%)$ & $63(75 \%)$ \\
\hline & Hadansho & 117 & $26(22.2 \%)$ & $91(77.8 \%)$ \\
\hline & Mako & 133 & $19(14.3 \%)$ & $124(85.7 \%)$ \\
\hline Overall prevalence & Total & 334 & $66(19.8 \%)$ & $268(80.2 \%)$ \\
\hline
\end{tabular}

Association of risk factors with E. histolytica infection among school children

In this study significant relationships were observed between $E$. histolytica infection and dependent variable and some of independent variables. The result showed that mother's occupation, hand wash 
before eating, hand wash after defecation and awareness about amoebiasis showed significant association $(p<0.05)$ with prevalence of E. histolytica in school children (Table 4 and 5$)$. 
Table 4

Potential risk factors associated with E. histolytica infections

\begin{tabular}{|c|c|c|c|c|c|c|}
\hline \multirow[t]{2}{*}{ Variables } & \multirow[t]{2}{*}{ Category } & \multirow{2}{*}{$\begin{array}{l}\mathrm{EH} \\
+\mathrm{Ve}\end{array}$} & \multirow{2}{*}{$\begin{array}{l}\text { EH } \\
-\mathrm{Ve}\end{array}$} & \multirow[t]{2}{*}{ COR (95\% Cl) } & \multirow[t]{2}{*}{ AOR (95\% Cl) } & \multirow[t]{2}{*}{$\begin{array}{l}\mathrm{p} \text { - } \\
\text { value }\end{array}$} \\
\hline & & & & & & \\
\hline \multirow{5}{*}{$\begin{array}{l}\text { Father's } \\
\text { educational } \\
\text { status }\end{array}$} & $\begin{array}{l}\text { Unable to } \\
\text { write and read }\end{array}$ & 4 & 34 & 1 & 1 & \\
\hline & $\begin{array}{l}\text { Able to write } \\
\text { and read only }\end{array}$ & 13 & 60 & $2.297(0.729,7.239)$ & $1.099(0.195,6.190)$ & 0.915 \\
\hline & $\begin{array}{l}\text { Elementary } \\
\text { school }\end{array}$ & 9 & 46 & $1.247(0.574,2.713)$ & $0.857(0.227,3.234)$ & 0.819 \\
\hline & $\begin{array}{l}\text { Secondary } \\
\text { school }\end{array}$ & 20 & 54 & $1.381(0.580,3.294)$ & $0.949(0.204,4.409)$ & 0.947 \\
\hline & $\begin{array}{l}\text { Above } \\
\text { diploma }\end{array}$ & 20 & 74 & $0.730(0.358,1.487)$ & $0.633(0.214,1.870)$ & 0.408 \\
\hline \multirow{5}{*}{$\begin{array}{l}\text { Mother's } \\
\text { educational } \\
\text { status }\end{array}$} & $\begin{array}{l}\text { Unable to } \\
\text { write and read }\end{array}$ & 6 & 21 & 1 & 1 & \\
\hline & $\begin{array}{l}\text { Able to write } \\
\text { and read only }\end{array}$ & 17 & 93 & $1.361(0.454,4.072)$ & $0.600(0.051,7.012)$ & 0.684 \\
\hline & $\begin{array}{l}\text { Elementary } \\
\text { school }\end{array}$ & 9 & 52 & $2.127(0.951,4.753)$ & $0.898(0.194,4.151)$ & 0.891 \\
\hline & $\begin{array}{l}\text { Secondary } \\
\text { school }\end{array}$ & 20 & 66 & $2.247(0.879,5.746)$ & $0.639(0.136,2.996)$ & 0.570 \\
\hline & $\begin{array}{l}\text { Above } \\
\text { diploma }\end{array}$ & 14 & 36 & $1.283(0.580,2.841)$ & $0.708(0.191,2.623)$ & 0.605 \\
\hline \multirow{4}{*}{$\begin{array}{l}\text { Father's } \\
\text { occupation }\end{array}$} & Merchant & 26 & 106 & 1 & 1 & \\
\hline & $\begin{array}{l}\text { Government } \\
\text { worker }\end{array}$ & 27 & 95 & $0.895(0.387,2.072)$ & $0.948(0.242,3.710)$ & 0.939 \\
\hline & Daily laborer & 4 & 26 & $0.772(0.334,1.787)$ & $1.209(0.276,5.294)$ & 0.801 \\
\hline & Farmer & 9 & 41 & $1.427(0.398,5.112)$ & $1.754(0.346,8.902)$ & 0.498 \\
\hline \multirow{5}{*}{$\begin{array}{l}\text { Mother's } \\
\text { occupation }\end{array}$} & House wife & 24 & 119 & 1 & 1 & \\
\hline & Merchant & 27 & 100 & $2.833(0.769,8.442)$ & $1.922(0.230,16.066)$ & 0.547 \\
\hline & $\begin{array}{l}\text { Government } \\
\text { worker }\end{array}$ & 10 & 19 & $2.116(0.577,7.765)$ & $1.287(0.150,11.073)$ & 0.818 \\
\hline & Daily laborer & 1 & 23 & $1.086(0.255,4.617)$ & $0.493(0.037,6.613)$ & 0.594 \\
\hline & Farmer & 4 & 7 & $3.143(1.255,5.235)$ & $7.110(1.035,18.906)$ & 0.047 \\
\hline
\end{tabular}


Table 5

Association between behavioral and environmental factors with prevalence of E. histolytica

\begin{tabular}{|c|c|c|c|c|c|c|}
\hline Variable & Category & $\begin{array}{l}\text { EH } \\
\text { +ve }\end{array}$ & $\begin{array}{l}\text { E.H } \\
\text {-ve }\end{array}$ & $\begin{array}{l}\text { COR } \\
(95 \% \mathrm{Cl})\end{array}$ & $\begin{array}{l}\text { AOR } \\
(95 \% \mathrm{Cl})\end{array}$ & $\begin{array}{l}\mathrm{p}- \\
\text { value }\end{array}$ \\
\hline \multirow[t]{2}{*}{ Source of drinking water } & Tap & 63 & 249 & $\begin{array}{l}0.624 \\
(0.179,2.175)\end{array}$ & $\begin{array}{l}0.487 \\
(0.123,1.925)\end{array}$ & 0.305 \\
\hline & $\begin{array}{l}\text { Ground } \\
\text { Water }\end{array}$ & 3 & 19 & 1 & 1 & \\
\hline \multirow[t]{4}{*}{ Water storage } & Tank & 12 & 57 & 1 & 1 & \\
\hline & Jerican & 45 & 163 & $\begin{array}{l}0.452 \\
(0.093,2.93)\end{array}$ & $\begin{array}{l}0.209 \\
(0.035,1.239)\end{array}$ & 0.085 \\
\hline & Baldy & 7 & 27 & $\begin{array}{l}0.345 \\
(0.078,1 . \\
527)\end{array}$ & $\begin{array}{l}0.209 \\
(0.041,1.067)\end{array}$ & 0.060 \\
\hline & Clay spot & 2 & 21 & $\begin{array}{l}0.367 \\
(0.069,1.955)\end{array}$ & $\begin{array}{l}0.179 \\
(0.027,1.160)\end{array}$ & 0.071 \\
\hline \multirow[t]{2}{*}{$\begin{array}{l}\text { Status of water } \\
\text { container }\end{array}$} & Covered & 63 & 251 & $\begin{array}{l}0.703 \\
(0.200,2.474)\end{array}$ & $\begin{array}{l}0.646 \\
(0.156,2.663)\end{array}$ & 0.545 \\
\hline & Uncovered & 3 & 17 & 1 & 1 & \\
\hline \multirow[t]{2}{*}{$\begin{array}{l}\text { Treatment of water at } \\
\text { home }\end{array}$} & Yes & 16 & 69 & $\begin{array}{l}1.084 \\
(0.579,2.026)\end{array}$ & $\begin{array}{l}0.914 \\
(0.407,2.052)\end{array}$ & 0.828 \\
\hline & No & 50 & 199 & 1 & 1 & \\
\hline \multirow{2}{*}{$\begin{array}{l}\text { Presence of latrine at } \\
\text { home }\end{array}$} & Yes & 66 & 268 & & & \\
\hline & No & - & - & & & \\
\hline \multirow[t]{2}{*}{$\begin{array}{l}\text { Presence of water at } \\
\text { latrine }\end{array}$} & Yes & 29 & 107 & $\begin{array}{l}0.848 \\
(0.492,1.461)\end{array}$ & $\begin{array}{l}0.860 \\
(0.422,1.751)\end{array}$ & 0.677 \\
\hline & No & 37 & 161 & 1 & 1 & \\
\hline \multirow[t]{2}{*}{ Sewage disposal } & Garbage pit & 26 & 86 & $\begin{array}{l}0.727 \\
(0.417,1.268)\end{array}$ & $\begin{array}{l}0.492 \\
(0.236,1.027)\end{array}$ & 0.059 \\
\hline & $\begin{array}{l}\text { Outside the } \\
\text { compound }\end{array}$ & 40 & 182 & 1 & 1 & \\
\hline
\end{tabular}




\begin{tabular}{|c|c|c|c|c|c|c|}
\hline Variable & Category & $\begin{array}{l}\text { EH } \\
+\mathrm{ve}\end{array}$ & $\begin{array}{l}\text { E.H } \\
-v e\end{array}$ & $\begin{array}{l}\text { COR } \\
(95 \% \mathrm{Cl})\end{array}$ & $\begin{array}{l}\text { AOR } \\
(95 \% \mathrm{Cl})\end{array}$ & $\begin{array}{l}\mathrm{p} \text { - } \\
\text { value }\end{array}$ \\
\hline \multirow{3}{*}{$\begin{array}{l}\text { Hand wash habit before } \\
\text { feeding }\end{array}$} & Yes & 60 & 207 & 0.339 & 0.322 & 0.021 \\
\hline & & & & $(0.140,0.823)$ & $(0.123,0.843)$ & \\
\hline & No & 6 & 61 & 1 & 1 & \\
\hline \multirow{5}{*}{$\begin{array}{l}\text { Hand wash habit after } \\
\text { defecation }\end{array}$} & No & 22 & 84 & 1 & 1 & \\
\hline & Water only & 34 & 123 & 0.626 & 0.544 & 0.195 \\
\hline & & & & $(0.277,1.417)$ & $(0.217,1.366)$ & \\
\hline & Water and soap & 10 & 61 & 0.593 & 0.396 & 0.037 \\
\hline & & & & $(0.275,1.28)$ & $(0.165,0.946)$ & \\
\hline \multirow{3}{*}{$\begin{array}{l}\text { Habit of eating } \\
\text { unwashed fruits }\end{array}$} & Yes & 43 & 165 & 0.857 & 1.732 & 0.127 \\
\hline & & & & $(0.488,1.505)$ & $(0.855,3.510)$ & \\
\hline & No & 23 & 103 & 1 & 1 & \\
\hline \multirow{3}{*}{$\begin{array}{l}\text { Dirty materials in the } \\
\text { fingers }\end{array}$} & Yes & 16 & 89 & 1.554 & 0.556 & 0.142 \\
\hline & & & & $(0.838,2.882)$ & $(0.254,1.218)$ & \\
\hline & No & 50 & 179 & 1 & 1 & \\
\hline \multirow[t]{3}{*}{ Habit of nail trim } & Yes & 64 & 240 & 0.268 & 4.543 & 0.070 \\
\hline & & & & $(0.062,1.154)$ & $(0.883,23.36)$ & \\
\hline & No & 2 & 28 & 1 & 1 & \\
\hline \multirow{3}{*}{$\begin{array}{l}\text { Awareness about } \\
\text { ameba }\end{array}$} & Yes & 9 & 61 & 1.866 & 0.355 & 0.027 \\
\hline & & & & $(0.874,3.986)$ & $(0.142,0.889)$ & \\
\hline & No & 57 & 207 & 1 & 1 & \\
\hline
\end{tabular}

\section{Discussions}

Amoebiasis is the second leading cause of death from parasitic disease globally. Entamoeba histolytica the causative protozoan parasite is a potent pathogen and very infrequent cause of childhood diarrhea or dysentery in developing countries (Black and Lanata 2002). The present study reports an overall frequency of E. histolytica in 334 samples collected from three elementary schools of Arsi town, West Zone of Ethiopia with $19.76 \%$ of the cases (66/334). The findings of this study confirmed a trend of high risk of E. histolytica infection among the school children as shown by other local studies, $17.1 \%$ in Western Gojjam (Mulusew 2014) 16.5\% in Chencha town, Southern Ethiopia (Abossie and Seid 2014) and 
elsewhere, $18.6 \%$ in Malaysia (Ngui et al. 2011) and up to 30\% in Iran (Nazarian 1973; Sheiban and Rezaian 1981). In contrast, the most recent studies among school children in Ethiopia demonstrated $12.9 \%$ of the prevalence rate of E. histolytica (Mengistu and Berhanu 2004; Desta et al. 2014). Interestingly, the high prevalence of E. histolytica among the school children was recorded by the researchers of Bahir Dar (24.5\%) and Gurage Zone of Ethiopia (27.3\%) (Hailegebrie 2017; Melesse et al. 2017). These variations may be due to use of transmission and pathogenesis as well as other risk factors which favor the persistence of this infection that may contribute to high prevalence of Entamoeba infection (Ngui et al. 2012).

This study extends the observation that, infection of E. histolytica was more prevalent in male student 34 $(20.6 \%)$ than female $32(18.9 \%)$, however, it was not statistically significant. There was no any significant association between sex and prevalence of the parasite. These findings are supported by results of Zeb et al. (2018) and Amaechi et al. (2017). This difference might be due to male have more outdoor works in villages and expose to the more unhygienic environment (Abossie and Seid 2014). This result was inconsistent with the study conducted in Benishangul Gumuz which observed that the prevalence rate is higher in female students (39.36\%) as compared to male students (31.88\%) (Gebremichael 2016).

Results also show that $E$. histolytica found more prevalent in 5-9 age groups (20.6\%) than $>15(16.7 \%)$ age group. But, there was no statically significant association between prevalence and age. This finding is further confirmed with the study done in Pakistan (Zeb et al 2018), and in Nigeria (Amaechi et al. 2017).

Many studies reported that there was a web of risk factors associated with the high prevalence of protozoa and other parasitic infections which includes habit of hand washing before eating, hand washing after defection, age, inadequate sanitation, untreated water supply, low level of parental education, poor geographical and personal hygiene [Al-Mekhlafi et al. 2007; Adams et al. 2004; Rajeswari et al. 1994]. Using multivariate analysis, the present study confirmed that children mother's occupation [AOR $=7.11 ; 95 \% \mathrm{Cl}(1.03,18.90)]$, hand wash before eating $[A O R=0.32 ; 95 \% \mathrm{Cl}(0.12,0.84]$, hand wash after defecation $[\mathrm{AOR}=0.396 ; 95 \% \mathrm{Cl}(0.165,0.946)]$ (Melesse et al. 2017) and awareness about amoebiasis $[A O R=0.35 ; 95 \% \mathrm{Cl}(0.142,0.889)]$ were significantly associated with $E$. histolytica infection (Mulusew 2014; Desta et al. 2014; Melesse et al. 2017).

Most amoebic studies that identified Entamoeba histolytica infection in Ethiopia were performed without the distinction of the separate species. This is possibly due to the lack of laboratory facilities and well trained technical staff. This investigation represents the first time research to use antigen detection kit. In the present study, the prevalence rate of E. histolytica was different by microscopy and antigen detection kit. Those samples were positive by microscopy again tested by antigen detection test, each was found negative. It is well known fact that diagnosis of E. histolytica by microscopic examination is based on protozoan morphology and unable to differentiate among protozoa with similar morphological features. It is also possible that the samples which were positive by microscopy but not antigen detection test may belong to other common amoebas. It proves that diagnostic sensitivity and specificity of microscopic 
examination to detect E. histolytica in stool is low (Haque et al. 1995; WHO 1997; Tanyuksel and Petri 2003; Haque and Petri 2006) but one study observed that TechLab enzyme-linked immunosorbent assay (ELISA) was less sensitive than microscopy (Fotedar et al. 2007). Therefore, a more sensitive method such as Real-Time PCR with specific primers for all amoebas species should be considered in future study.

\section{Conclusions And Recommendations}

Amoebiasis infections is major public health concerns and highly prevalent among the poor and socioeconomically deprived rural and remote communities of Africa including Ethiopia. According to several studies it is associated with poverty, poor environmental sanitation and lack of clean water supply; it is highly needed that these factors should be addressed effectively. Development of socioeconomic status, sanitation, health education to promote awareness about health and hygiene together with mass deworming under national health development programme are better strategies to control these infections. The present study could help the government to hit the infected areas; improve sanitation to reduce the level of transmission of E. histolytica with effective control measures in, these rural community, especially children who are the future of nation.

\section{Declarations}

\section{Funding}

No specific fund was received for the proposed work.

\section{Competing interests}

The Authors declare that they don't have any conflict of interest.

\section{Author contributions}

Conceptualization: [Sunil Tulshiram Hajare, Feleke Eriso], Methodology: [Feleke Eriso, Geribe Bushura Roro] investigation \& Data collection: [Geribe Bushura Roro] Writing - original draft preparation: [Awdah M Al-Hazimi, Mohammed Kuddus]; Writing - review and editing: [Sunil Tulshiram Hajare; Mohammed Kuddus], Supervision: [Feleke Eriso, Awdah M Al-Hazimi]. All authors read and approved the final manuscript.

\section{Data availability}

Not applicable. However, raw data can be obtained from the corresponding author upon request.

\section{Ethical approval}


The study protocol was approved by Dilla University Ethical Committee (DUEC Ref Du/241/21). Oral consent had been taken from school directors. Informed consent was obtained from all students recruited in the study. Written informed consent was obtained from the parents. The questionnaires concerning the prevalence of study were recorded during sample collection. Apart from these, students were asked to fill the questionnaire and assist during sample collection. The information obtained during the study period was kept confidential. Paper data were secured in a locked cabinet confidentially and computer based data were protected with passwords. Except the research team members, no one has permission to access patient data

\section{Acknowledgements}

The authors would like to thanks to Arsi Hospital Authorities for providing E. histolytica II test (TechLab, Inc., Blacksburg, VA) kits and assist in technical aspects.

\section{References}

1. Abossie, A. and Seid, M. (2014) Assessment of the prevalence of intestinal parasitosis and associated risk factors among primary school children in Chencha town, Southern Ethiopia. BMC Public Health 14, 166. https://doi.org/10.1186/1471-2458-14-166.

2. Adams VJ, Lombard CJ, Dhansay MA, Markus MB, Fincham JE (2004) Efficacy of albendazole against the whipworm Trichuris trichiura: a randomized controlled trial. S Afr Med J 94: 972-976.

3. Adeyeba, O. A and Akinlabi, A. (2002) Intestinal parasitic infections among school children in a rural community, southwest Nigeria. Nigerian Journal of Parasitology, 23: 11-18.

4. Al-Mekhlafi HMS, Atiya AS, Lim YAL, Mohammed Mahdy AK, Wan Ariffin WA, et al. (2007) An unceasing problem: soil-transmitted helminthiases in rural Malaysian communities. Southeast Asian J Trop Med Pub Health 38: 998-1007. View Article Google Scholar.

5. Amaechi EC, Ohaeri CC, Ukpai OM, Ukoha UK, Nwachukwu PU, Ejike BU (2017) Prevalence and clinical aspects of Wuchereria bancrofti among inhabitants of a resource limited irrigation project community, north central Nigeria. Asian Pac. J. Trop. Dis. 7(1): 32-35.

6. Beyene, A., Hailu, T., Faris, K. and Helmut Kloos. (2015) Current state and trends of access to sanitation in Ethiopia and the need to revise indicators to monitor progress in the Post-2015 era. BMC Public Health 15, 451 https://doi.org/10.1186/s12889-015-1804-4.

7. Black, R. E., and C. F. Lanata (2002) Epidemiology of diarrheal diseases in developing countries, p. 11-29. In M. J. Blaser, P. D. Smith, J. I. Ravdin, H. B. Greenberg, and R. L. Guerrant (ed.), Infections of the gastrointestinal tract, 2nd ed. Lippincott Williams and Wilkins, Philadelphia, Pa. [Ref list]

8. Daniel WW (1999) Biostatistics: a foundation for analysis in the health science. 7th ed. New York: John Wiley \& Sons. [Google Scholar].

9. Desta Haftu, Negussie Deyessa and Eskzyiaw Agedew. (2014) Prevalence and Determinant Factors of Intestinal Parasites among School Children in Arba Minch Town, Southern Ethiopia. American 
Journal of Health Research, 2(5): 247-254.

10. Erko, B., H. Birrie, and Tedla, S. (1995) Amoebiasis in Ethiopia. Trop. Geogr. Med. 47(1): 30-32.

11. Feleke Eriso (2014) Intestinal Parasitic Infections in Elementary Schools Children at Dilla Town and its Peripheral Villages. Journal of Infection Endemic Disease, 4(2): 88-

95.file:///C:/Users/welcome/Downloads/entamobia.pdf

12. Fotedar, R., Stark, D., Beebe, N., Marriott, D., Ellis, J., \& Harkness, J. (2007). Laboratory diagnostic techniques for Entamoeba species. Clinical microbiology reviews, 20(3), 511-532. https://doi.org/10.1128/CMR.00004-07

13. Gebremichael Gebretsadik (2016) Prevalence of Intestinal Parasites and Associated Risk Factors Among Schoolchildren of Homesha District (Woreda) in Benishangul-Gumuz Regional State, Western Ethiopia, Journal of Family Medicine and Health Care. Vol. 2, No. 4, pp. 57-64. doi: 10.11648/j.jfmhc.20160204.16.

14. Hailegebriel T. (2017) Prevalence of intestinal parasitic infections and associated risk factors among students at Dona Berber primary school, Bahir Dar, Ethiopia. BMC infectious diseases, 17(1), 362. https://doi.org/10.1186/s12879-017-2466-x

15. Haque R, Neville LM, Hahn P, Petri WA (1995) Rapid diagnosis of Entamoeba infection by using Entamoeba and Entamoeba histolytica stool antigen detection kits. J Clin Microbiol 33:2558-2561.

16. Haque R, Petri WA (2006) Diagnosis of amebiasis in Bangladesh. Arch Med Res 37:272-275.

17. Haque, R., Mollah, N. U., Ali, I. K., Alam, K., Eubanks, A., Lyerly, D., \& Petri, W. A., Jr (2000). Diagnosis of amebic liver abscess and intestinal infection with the TechLab Entamoeba histolytica II antigen detection and antibody tests. Journal of clinical microbiology, 38(9), 3235-3239. https://doi.org/10.1128/JCM.38.9.3235-3239.2000

18. Haque, R., Mondal, D., Duggal, P., Kabir, M., Roy, S., Farr, B. M., Sack, R. B., \& Petri, W. A., Jr (2006) Entamoeba histolytica infection in children and protection from subsequent amebiasis. Infection and immunity, 74(2), 904-909. https://doi.org/10.1128/IAl.74.2.904-909.2006

19. Hosmer, D. W, and Lemeshow S. (2000) Applied Logistic Regression New York: 2nd ed. John Wiley \& Sons Editions; Pp: 91-116.

20. https://www.unicef.org/ethiopia/water-sanitation-and-hygiene-wash

21. Melesse Birmeka, Kelebesa Urga, and Beyene Petros (2017) Prevalence and determinants of intestinal parasitic infections among primary schoolchildren in Gurage zone, south central Ethiopia. E-Cronicon Microbiology, 8.2: 59-70.

22. Mendoza Cavazos, C. \& Knoll, L. J. (2020) Entamoeba histolytica: Five facts about modeling a complex human disease in rodents. PLoS pathogens, 16(11), e1008950. https://doi.org/10.1371/journal.ppat.1008950

23. Mengistu Legesse, Berhanu Erko (2004) Prevalence of intestinal parasite among school children in rural area close to the Southeast of Lake Langano, Ethiopia. Ethiopian Journal of Health Development, 18(2): 116-120. 
24. Mulusew Andualem, (2014) Parasitic Infection and Associated Factors among the Primary School Children in Motta Town, Western Amhara, Ethiopia. American Journal of Public Health Research, 2(6): 248-254.

25. Nazarian, I. (1973) Intestinal parasitic infestation in Fars province, Iran. Z. Tropenmed. Parasitol. 24:45-50. [PubMed] [Google Scholar] [Ref list].

26. Ngui, R., Angal, L., Fakhrurrazi, S. A., Lian, Y. L., Ling, L. Y., Ibrahim, J., \& Mahmud, R. (2012) Differentiating Entamoeba histolytica, Entamoeba dispar and Entamoeba moshkovskii using nested polymerase chain reaction (PCR) in rural communities in Malaysia. Parasites \& vectors, 5, 187. https://doi.org/10.1186/1756-3305-5-187

27. Ngui, R., Ishak, S., Chuen, C. S., Mahmud, R., \& Lim, Y. A. (2011) Prevalence and risk factors of intestinal parasitism in rural and remote West Malaysia. PLoS neglected tropical diseases, 5(3), e974. https://doi.org/10.1371/journal.pntd.0000974

28. Parija SC, Mandal J, Ponnambath DK. (2014) Laboratory methods of identification of Entamoeba histolytica and its differentiation from look-alike Entamoeba spp. Trop Parasitol;4:90-5

29. Petri, W.A.Jr. and Singh, U. (2006) Enteric Amoebiasis, In: Guerrant, R.L., Walker, D.H., Weller, P.F. eds. Tropical Infections diseases. Principles, pathogens and practice. 2nd Ed. Philadelphia, P.A: Elesier Churchill Livingstone, pp 967-983.

30. Rajeswari B, Sinniah B, Hussein H (1994) Socioeconomic factor associate with intestinal parasites among children living in Gombak, Malaysia. Asia Pac J Clin Nutr 7: 21-25.

31. Schmidt, G.D., and Roberts, L.S. (2000) Foundations of Parasitology, 6th Ed. New York: Mc Graw- Hill Companies, Pp:767

32. Sheiban, F., and M. Rezaian (1981) A study on intestinal protozoa in seven villages of Bandar Abbas, southern Iran. Iran. J. Public Health 10:45-55. [Google Scholar] [Ref list].

33. Stanley S. L., Jr (2003) Amoebiasis. Lancet (London, England), 361(9362), 1025-1034. https://doi.org/10.1016/S0140-6736(03)12830-9

34. Tanyuksel M, Petri WA (2003) Laboratory diagnosis of amebiasis. Clin Microbiol Rev 16:713-729.

35. WHO (1997) UNESCO report of a consultation of experts on amoebiasis. Wkly Epidemiol Rec 72:9799.

36. WHO/PAHO/UNESCO report. A consultation with experts on amoebiasis. Mexico City, Mexico 28-29 January, 1997. (1997). Epidemiological bulletin, 18(1), 13-14.

37. Zeb, A., Qureshi, W. A., Khan, L., Mansoor, A., Ullah, S and Irfan, M. (2018). Prevalence of Entamoeba histolytica in district Buner Khyber Pakhtunkhwa, Pakistan. Journal of Entomology and Zoology Studies, 6 (1): 185-188.

\section{Figures}




\section{Figure 1}

Morphology of the diagnostic stage of Entameba histolytica, cyst healed and treated with Resolution 1200/inch. 